\title{
Woody Species Stand Structure and Regeneration Status in Long Jack (Eurycoma longifolia Jack) Habitat in Batang Lubu Sutam Forest, Padang Lawas, North Sumatra
}

\author{
Arida Susilowati ${ }^{1, *}$, Asep Hidayat ${ }^{2}$, Anita Zaitunah ${ }^{1}$, Melya Riniarti ${ }^{3}$, Rio Afandi ${ }^{1}$ \\ ${ }^{1}$ Faculty of Forestry, University of Sumatera Utara. Jl. Tri Darma Ujung No 1, Medan, 20155, Sumatera Utara, Indonesia \\ ${ }^{2}$ Forest Microbiology Laboratory, Forest Research and Development Centre, Research, Development and Innovation Agency, \\ Ministry of Environment and Forestry. Jl. Gunung Batu No. 5, Bogor 16610, West Java, Indonesia \\ ${ }^{3}$ Department of Forestry, Faculty of Agriculture, University of Lampung. Jl. Prof. Dr. Sumantri Brojonegoro No. 1, Bandar \\ lampung, 35141, Lampung, Indonesia \\ * Corresponding Author. E-mail address: arida.susilowati@usu.ac.id
}

\section{ARTICLE HISTORY:}

Received: 8 June 2021

Peer review completed: 9 November 202 Received in revised form: 14 November 2021 Accepted: 18 November 2021

\section{KEYWORDS:}

Long jack (Eurycoma longifolia) Regeneration

Species composition

Vegetation structure
(C) 2021 The Author(s). Published by Department of Forestry, Faculty of Agriculture, University of Lampung in collaboration with Indonesia Network for Agroforestry Education (INAFE). This is an open access article under the CC BY-NC license:

https://creativecommons.org/licenses/by$\mathrm{nc} / 4.0 \%$.

\begin{abstract}
Long jack (Eurycoma longifolia) is a medicinal plant that has become a common target for exploitation, leading to a population decline in natural forests. This study aimed to determine the stand structure and regeneration status of E. longifolia tree habitat in Batang Lubu Sutam Forest, Padang Lawas, North Sumatra. The research was performed through vegetation analysis using a purposive sampling technique with a randomized sample plot based on the presence of E. longifolia. A total of 181 plots were established in this study. The results showed that the horizontal structure of tree species in the research area had an inverted J-shape pattern, indicating that the number of trees decreased as the diameter increased. The vertical structure showed that all strata were found in the research location, dominated by stratum $\mathrm{C}$. This condition indicated that the forest was in good condition. The regeneration status of 48 species in the location showed different categories. Thirty species $(62.50 \%)$ were classified as good regeneration, ten species $(18.75 \%)$ as new regeneration, and four species $(8.30 \%)$ as poor and no regeneration. The high proportion of trees with good regeneration showed that the forest community could survive despite environmental or anthropogenic stress.
\end{abstract}

\section{Introduction}

Eurycoma longifolia, locally known as long jack, pasak bumi, or tongkat ali, is one of the Simaroubaceae family members with distribution ranging from Indonesia, Malaysia, Vietnam, Cambodia, Myanmar, Laos to Thailand (Chen et al. 2015). In Indonesia, E. longifolia grows naturally and randomly across various regions in Sumatra and Borneo islands (Rosmaina and Zulfahmi 2013). For traditional people, E. longifolia is known as a medicinal plant for stomachache, fever, gingivitis, ascariasis, dysentery, and postnatal tonic (Damayanti and Sukesi 2014). Several pharmacological studies on E. longifolia also reported a potential aphrodisiac (Chen et al. 2015), anti-malaria (Low et al. 2013), anticancer (Falah and Yuliani 2011), anti-microbial (Kong et al. 2014), anti-inflammation (Tran et al. 2014), and anti-diabetic (Lahrita et al. 2015). E. longifolia is one of the medicinal plants widely used by indigenous peoples in North Sumatra 
to treat fever and malaria (Susilowati et al. 2019a). The information on the production volume and export quota of E. longifolia in North Sumatra is limited because the E. longifolia trade is generally a traditional and close market (Sihotang and Rahmawati 2019).

Increasing market demand and little or no plantation effort have resulted in a drastic reduction in the natural population. Moreover, the government declared E. longifolia as a protected species since 2006 (Susilowati et al. 2019a). Illegal E. longifolia harvesting also impacts the species composition and the natural forest where it grows. Forests that have been disturbed, such as by logging, have altered yield potential, structure, and species composition. Aside from the natural forest, the vegetation in the secondary forest has also experienced natural regeneration due to natural or anthropogenic disturbances over a specific period, which might significantly alter the vegetation structures and species compositions (Heriyanto et al. 2019; Yuniawati and Tampubolon 2021). Density, basal area, distribution, and diameter classes could be used to describe these component structures (Wahyuni and Mokodompit 2016).

Species regeneration status is linked with forest structure and composition (Rozak et al. 2020). Study on forest regenerations has an important implication for the sustainability of natural forests (Rawat et al. 2018). Baseline data in plant species and community composition is also a prerequisite to understanding the whole ecosystem structure and functions (Susilowati et al. 2019b). The forest area in Batang Lubu Sutam is a primary E. longifolia habitat with a great potential for development. On the other hand, deforestation, habitat fragmentation, forest fires, and natural disasters such as landslides endanger the forest's natural biodiversity and suppress the component species, particularly the E. longifolia. The study on E. longifolia in Indonesia is limited, including the regeneration status of $E$. longifolia and the associated species in its habitat. Therefore, the research aimed to determine the stand structure and regeneration status of tree species in E. longifolia habitat.

\section{Materials and Methods}

The research was performed in the Batang Lubu Sutam Forest, Padang Lawas Regency, North Sumatra (Fig. 1). The Batang Lubu Sutam Forest is located in the restricted production forest Register Number 40, with only 500 ha of forestland remaining. The location's elevations range from $250-700 \mathrm{~m}$, with temperatures ranging from $27-30^{\circ} \mathrm{C}$, and relative humidity ranging from $65-90 \%$.
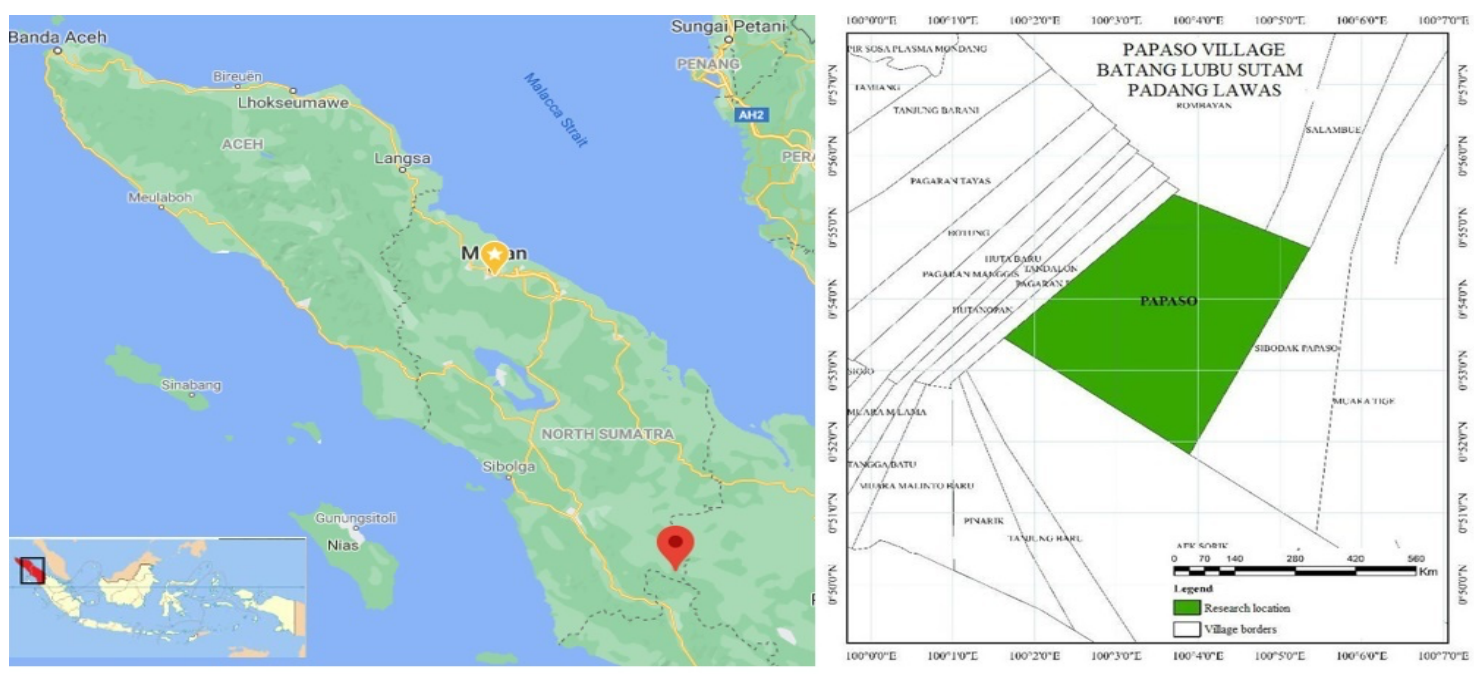

Fig. 1. Research location. 
Stand structure and regeneration status data collection were conducted using vegetation analysis methods. A total of 180 observation plots were established for collected data regarding species identity, the number of individuals, tree height, and diameter at breast height. The measurement was conducted at every growth stage consisting of seedling, sapling, pole, and tree stages.

\subsection{Stand Structure}

The stand structures measurements were conducted based on Siraj and Zhang (2012). All species were identified based on the local guide. Herbarium specimens were collected for further identification in Forest Research and Development Agency (FORDA) for the ambiguous species. The horizontal structure is described by diameter breast height distribution with five $\mathrm{cm}$ diameter class intervals (Pamoengkas and Exze 2019). In this research, diameter classes from $<10 \mathrm{~cm}$ (the lower) to the highest classes $(34.9 \mathrm{~cm})$. The vertical structure is described using the tree height distribution of tree species in the research location. Measurement of the vertical stand structure refers using the classification stratum A (height $>30 \mathrm{~m}$ ), stratum B (height 20-30 m), and stratum $\mathrm{C}$ (height 4-20 m).

\subsection{Regeneration Status}

Regeneration status was analyzed by calculating the proportion of juvenile stage (seedlings and saplings) with mature stage potential (pole and tree). The regeneration status classification was classified based on previous studies (Bogale et al. 2017; Rawat et al. 2018; Sarkar and Devi 2014):

1. Good regeneration (good) if numbers of existing seedling $>$ sapling $>$ mature tree.

2. Fair regeneration (fair) if numbers of existing seedling $>$ sapling $\leq$ mature tree.

3. Poor regeneration (poor) if a particular species only survived as wildings but did not progress to the seedling stage (even though the number of wildings might be fewer than, more than, or equal to mature trees).

4. No regeneration (none) if there were no species identified in sapling and seedling stages.

5. New regeneration (new) if there were no identified species in the mature stage but only in seedling and sapling stages.

\section{Results and Discussion}

\subsection{Stand Structure}

The stand structure can indicate the condition of ecosystems and biodiversity in a forest ecosystem ( $\mathrm{Su}$ et al. 2010). Information on species composition, regeneration status, and stand structure is required to confirm the success of forest management or conservation activity (Mishra et al. 2013; Teketay 2018). In addition, the stand composition and structure could be used to estimate long-term forest changes and monitor existing plant communities (Fisaha et al. 2013). The study of natural regeneration is essential for understanding dynamic processes in the forest and monitoring future changes in species composition caused by environmental changes or human activities (Sharma et al. 2014). Horizontal and vertical structures could be used to describe the condition of the stand structure. 


\subsubsection{Horizontal structure}

The distribution of tree diameter class is an important indicator of changes in the population structure and species composition of a forest. Therefore, it can be used to estimate the future trend of the population of a particular species (Damayanti et al. 2017). Based on the assessment of diameter class distributions, the population structure patterns of the woody species in the research location showed an inverted J-shape, an indication of stable population structure or healthy regeneration status (Heriyanto and Subiandono 2012).

The number of trees is dominated by the small-diameter class $(<10 \mathrm{~cm})$, reaching 889 individuals, then drastically declining in the 10-14.9 cm diameter class (Fig. 2). In the 15-19.9 cm diameter class, there was an increase in the number of individuals (171 individuals). In the 20-24.9 cm diameter class, identified trees reached 182 individuals. Lastly, in the 25-29.9 and 30-34.9 cm diameter classes, there were 56 and 10 individuals, respectively (Fig. 2). The curve that forms an inverted J-shape shows a drastic decline in tree populations along with the increasing tree diameter.

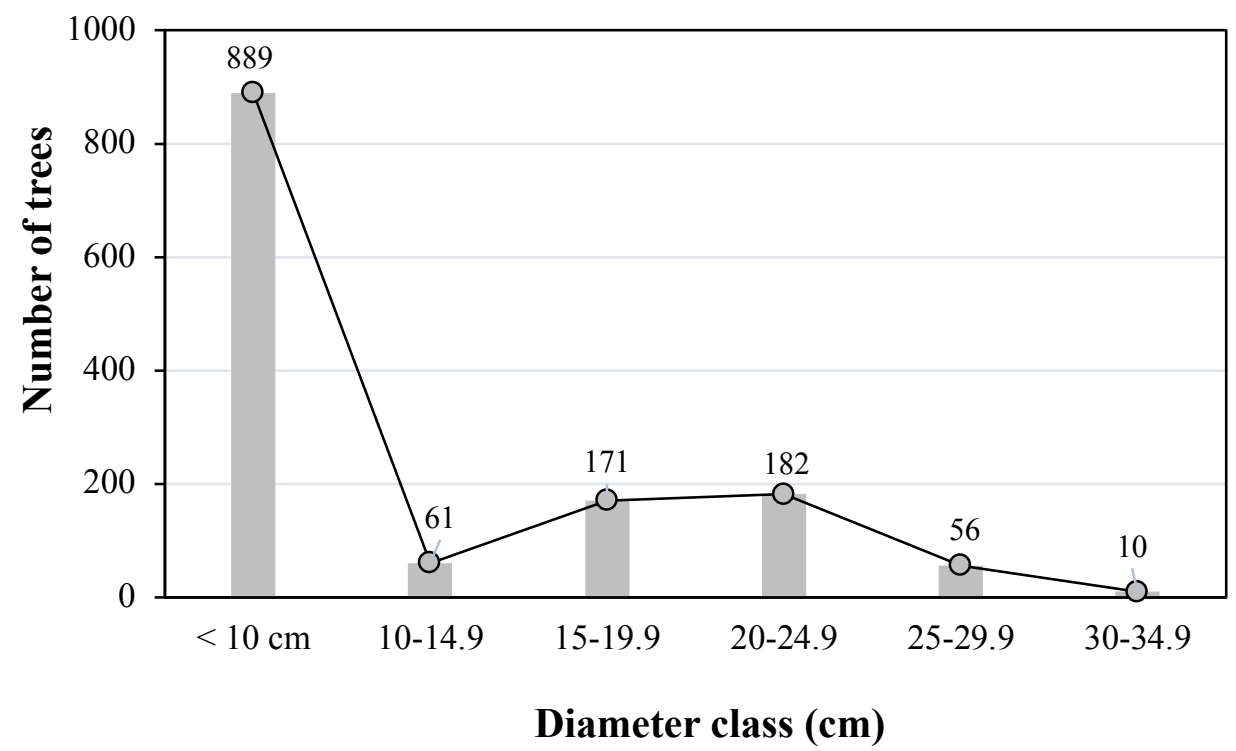

Fig. 2. Horizontal structure of tree species in Batang Lubu Sutam Forest.

Several valuable tree species, such as damar (Agathis dammara), meranti (Shorea sp.), and keruing (Dipterocarpus sp.), were already challenging to find in research locations. E. longifolia, on the other hand, was only utilized by locals for malaria treatment or personal use. Aside from that, Wardani and Susilo (2017) stated that several factors such as fallen trees, natural disasters (forest fires, earthquakes, landslides, pests and diseases outbreaks, and others) might impact natural regeneration.

\subsubsection{Vertical structure}

Crown stratification could depict light utilization patterns, dominant tree species, and trees that can grow under the shade (Naidu and Kumar 2016). According to the observation results, crown stratification in the research location is composed of stratum A-E (Fig. 3). Stratum C has the most individual numbers according to the vertical structure, followed by stratum $\mathrm{B}$ and $\mathrm{A}$. The vertical structure is closely related to habitat domination, caused by the enormous quantity of light from the sun and the availability of groundwater resources and nutrient availability, which 
influence the individual growth of local community components. According to Kusmana and Susanti (2015), only climax trees species and old age trees with low and discontinuous numbers could reach stratum A. Due to the apparent long process and competition among plants, only a small number reached stratum A.

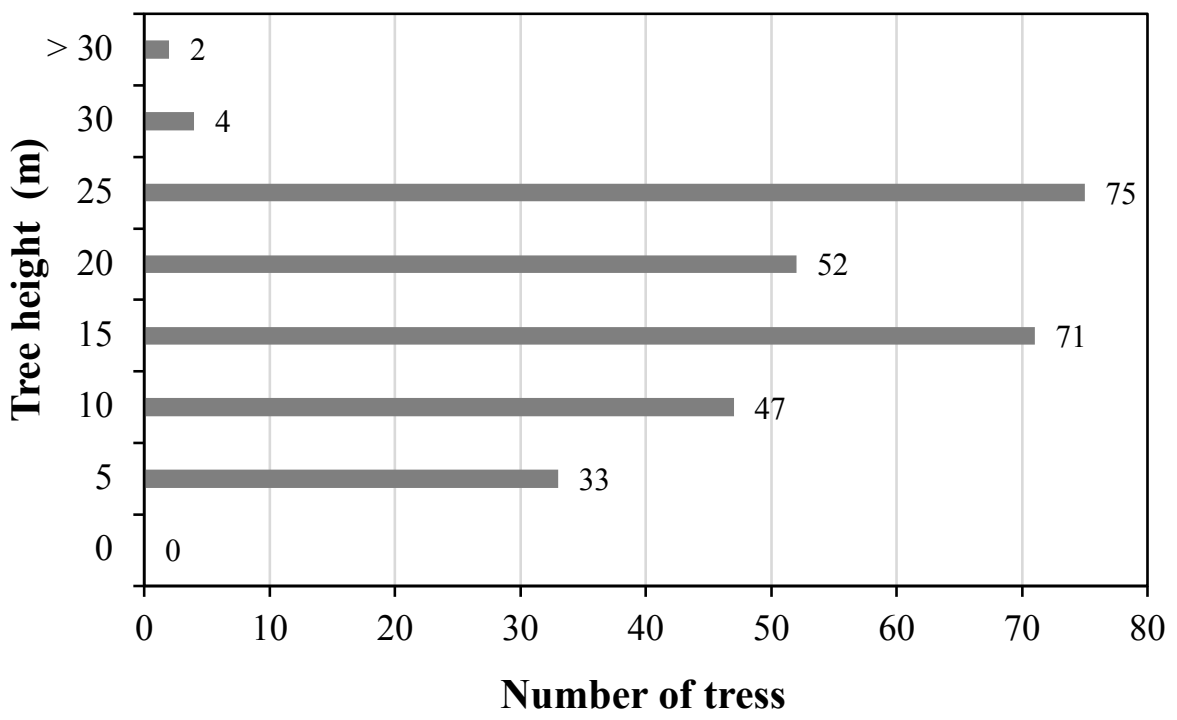

Stratum $A=>30 \mathrm{~m}$

Stratum $B=20-30 \mathrm{~m}$

Stratum $\mathrm{C}=4-20 \mathrm{~m}$
Stratum $\mathrm{D}=1-4 \mathrm{~m}$

Stratum $\mathrm{E}=0-1 \mathrm{~m}$

Fig. 3. Vertical structure of tree species in Batang Lubu Sutam Forest.

\subsection{Regeneration status}

Forty eight species were found in the research location (Table 1). As many as 30 species $(62.50 \%)$ showed good regeneration, and 4 species $(8.3 \%)$ showed no regeneration or none. As many as 10 species $(18.75 \%)$ were only found at seedling stages or classified as new regeneration, and 4 species $(8.30 \%)$ showed poor regeneration. E. longifolia's regeneration status was categorized as new regeneration. This regeneration status was given because there were no identified E. longifolia species in later stages. A similar case was also reported by Susilowati et al. (2019a) with no identifiable E. longifolia species at the mature stage in Batang Lubu Sutam forest. This was presumably due to the overharvesting of mature E. longifolia plants. In the early growth stage, the plant is more susceptible to various environmental stressors and anthropogenic disturbances, impairing the regeneration status (Sharma et al. 2014). Species with low regeneration status in their early stages are highly close to extinction. The low rate of natural regeneration of a particular species indicates that the population is in severe problem, which may risk its sustainability in the future (Pant and Samant 2012).

Richness and abundance are significantly related to species' potential regeneration status in spatial and temporal scales (Siburian et al. 2020). Forest regeneration is an essential part of how older trees are regularly regenerated by younger vegetation (Bogale et al. 2017). Unless there is massive environmental stress or interference due to human activity, the good regeneration status seen in future communities may be sustained. Tree species with poor or no regeneration, on the other hand, may lead to extinction in the future. As a result, a systematic management approach is required for their conservation and long-term sustainable use. 
Table 1. Regeneration status of species

\begin{tabular}{|c|c|c|c|c|c|}
\hline No & Scientific name & $\begin{array}{c}\text { Seedling } \\
\text { (individual/ha) }\end{array}$ & $\begin{array}{c}\text { Sapling } \\
\text { (individual/ha) }\end{array}$ & $\begin{array}{c}\text { Tree } \\
\text { (individual/ha) }\end{array}$ & $\begin{array}{c}\text { Regeneration } \\
\text { status }\end{array}$ \\
\hline 1 & Knema glaucia & 394.78 & - & 2.63 & None \\
\hline 2 & Spatholobus littoralis & $2,236.84$ & 336.84 & 11.84 & Good \\
\hline 3 & Castanopsis spp. & $1,578.95$ & 168.42 & 10.53 & Good \\
\hline 4 & Agathis dammara & 657.89 & 63.16 & 3.95 & Good \\
\hline 5 & Durio zibethinus & 263.16 & 63.16 & 1.32 & Good \\
\hline 6 & Cotylelobium spp. & $1,973.68$ & 210.53 & - & New \\
\hline 7 & Grapthophyllum pictum & - & 21.05 & - & New \\
\hline 8 & Vitex quinatta & 394.74 & 84.21 & 2.63 & Good \\
\hline 9 & Streblus elongates & $6,315.79$ & 884.21 & 42.10 & Good \\
\hline 10 & Macaranga lowii & 526.32 & 63.16 & 2.63 & Good \\
\hline 11 & Styrax spp. & 394.74 & 42.10 & - & New \\
\hline 12 & Dyera costulata & 657.89 & 42.10 & - & New \\
\hline 13 & Garcinia dioica & $5,394.74$ & 757.89 & 18.42 & Good \\
\hline 14 & Hevea brasiliensis & 657.89 & 63.16 & 2.63 & Good \\
\hline 15 & Swintonia glauca & $1,052.63$ & 147.37 & 9.21 & Good \\
\hline 16 & Diplospora malaccensis & $1,315.79$ & 189.47 & - & New \\
\hline 17 & Kroden & 263.16 & 84.21 & - & New \\
\hline 18 & Dipterocarpus spp. & $1,447.37$ & 168.42 & 9.21 & Good \\
\hline 19 & Cinnamomum porectum & 263.16 & - & 2.63 & None \\
\hline 20 & Pauzolzia zeylanica & 526.32 & 21.05 & 5.26 & Good \\
\hline 21 & Leea indica & 526.32 & 105.26 & 3.95 & Good \\
\hline 22 & Mangifera minor & 263.16 & 84.21 & 1.32 & Good \\
\hline 23 & Garcinia spp. & 131.58 & 42.10 & 2.63 & Good \\
\hline 24 & Anisoptera thrurifera & 394.74 & 42.10 & 1.32 & Good \\
\hline 25 & Elaeocarpus spp. & - & 21.05 & 1.32 & Poor \\
\hline 26 & Shorea gibbosa & 526.32 & 84.21 & 2.63 & Good \\
\hline 27 & Shorea platyclados & 789.47 & 105.26 & 3.95 & Good \\
\hline 28 & Shorea spp. & $3,289.47$ & 442.10 & 23.68 & Good \\
\hline 29 & Shorea leprosula & $6,315.79$ & $1,284.21$ & 48.68 & Good \\
\hline 30 & Ilex pleiobrachiata & - & - & 3.95 & Poor \\
\hline 31 & Shorea acuminate & $1,315.79$ & 336.84 & 13.16 & Good \\
\hline 32 & Shorea multiflora & $3,552.63$ & 589.47 & 25.00 & Good \\
\hline 33 & Blumeodendron kurzii & $2,105.26$ & 315.79 & 3.95 & Good \\
\hline 34 & Ganophyllum falcatum & 263.16 & 84.21 & 3.95 & Good \\
\hline 35 & Aporaso aurita & $1,447.37$ & 231.58 & 10.53 & Good \\
\hline 36 & Eurycoma longifolia & $6,315.79$ & 273.68 & - & New \\
\hline 37 & Parkia speciosa & & 168.42 & 1.32 & Poor \\
\hline 38 & Nephelium juglandifolium & 131.58 & 63.16 & - & New \\
\hline 39 & Dracontomelon dao & $3,947.37$ & 442.10 & 23.68 & Good \\
\hline 40 & Sindora spp. & 921.05 & 42.10 & 3.95 & Good \\
\hline 41 & Radermachera gigantea & - & 42.10 & - & None \\
\hline 42 & Macaranga hosei & - & - & 3.95 & Poor \\
\hline 43 & Dillenia indica & 394.74 & 42.10 & - & New \\
\hline 44 & Fragraea spp. & - & 42.10 & - & None \\
\hline 45 & Irvingia spp. & 131.58 & 42.10 & - & New \\
\hline 46 & Artocarpus odoratissimus & 394.74 & 42.10 & 3.95 & Good \\
\hline 47 & Archidendron sp. & $1,447.37$ & 421.05 & 11.84 & Good \\
\hline 48 & Eusyderoxilon zwageri & 526.32 & 84.21 & 2.63 & Good \\
\hline
\end{tabular}




\section{Conclusions}

The horizontal structure of Batang Lubu Forest showed an inverted J shape, showing the highest number of trees in the small-diameter class (lower than $10 \mathrm{~cm}$ ) and a decrease of trees as the diameter increased. The results indicated that the research location has a general pattern of natural forests. The vertical structure was dominated by stratum $\mathrm{C}$, indicating that the research location is still in good condition. Regeneration status of 48 identified species showed that 30 species $(62.50 \%)$ have good regeneration, 10 species $(18.75 \%)$ classified as new regeneration, 4 species $(8.30 \%)$ a poor regeneration, and 4 species $(8.30 \%)$ were categorized as no regeneration. E. longifolia was categorized as new regeneration status. Species with good regeneration status have the ability to sustain from any environmental stressor or anthropogenic disturbance. In contrast, species with none or poor regeneration status have the potential threat of extinction in the future. Therefore, a conservation strategy is needed for the existence of those species.

\section{References}

Bogale, T., Datiko, D., and Belachew, S. 2017. Structure and Natural Regeneration Status of Woody Plants of Berbere Afromontane Moist Forest, Bale Zone, South East Ethiopia; Implication to Biodiversity Conservation. Open Journal of Forestry 7: 352-371. DOI: 10.4236/ojf.2017.73021

Chen, Y., Phang, W. M., Mu, A. K. W., Chan, C. K., Low, B. S., Sasidharan, S., and Chan, K. L. 2015. Decreased Expression of Alpha-2-HS Glycoprotein in the Sera of Rats Treated with Eurycoma longifolia Extract. Frontiers in Pharmacology 6: 211. DOI: 10.3389/fphar.2015.00211

Damayanti, A., and Sukesi, T. W. 2014. Pengaruh Ekstrak Akar Pasak Bumi terhadap Larva Nyamuk Aedes aegypti. Jurnal Kesehatan Masyarakat 7(2): 259-267.

Damayanti, D. R., Bintoro, A., and Santoso, T. 2017. Permudaan Alami Hutan di Satuan Pengelolaan Taman Nasional (SPTN) Wilayah III Kuala Penet Taman Nasional Way Kambas. Jurnal Sylva Lestari 5(1): 92-104. DOI: 10.23960/js11592-104

Falah, L. N., and Yuliani, S. 2011. Lymphocyte Proliferation Activity MTT-Test of Ethanolic Extract of Pasak Bumi Root (Eurycoma longifolia Jack) on Induced 7, 12-Dimethylbenz [A] Anthracene (DMBA) Female Sprague Dawley Rat. Indonesian Journal of Cancer Chemoprevention 2(1): 188-193. DOI: 10.14499/indonesianjcanchemoprev2iss1pp187-192

Fisaha, G., Hundera, K., and Dalle, G. 2013. Woody Plants' Diversity, Structural Analysis and Regeneration Status of Wof Washa Natural Forest, North-east Ethiopia. African Journal of Ecology 51: 599-608. DOI: 10.1111/aje.12071

Heriyanto, N. M., and Subiandono, E. 2012. Komposisi dan Struktur Tegakan, Biomasa, dan Potensi Kandungan Karbon Hutan Mangrove di Taman Nasional Alas Purwo. Jurnal Penelitian Hutan dan Konservasi Alam 9(1): 23-32. DOI: 10.20886/jphka.2012.9.1.023-032 Heriyanto, N. M., Samsoedin, I., and Bismark, M. 2019. Biodiversity Flora and Fauna in the Region Forest Bukit Datuk Dumai Riau Province. Jurnal Sylva Lestari,7(1): 82-94. DOI: 10.23960/js11782-94

Kong, C., Yehye, W. A., Rahman, N. A., Tan, M. W., and Nathan, S. 2014. Discovery of Potential Anti-Infectives Against Staphylococcus aureus using a Caenorhabditis elegans Infection 
Model. BMC Complementary and Alternative Medicine 14(4): 2-17. DOI: 10.1186/14726882-14-4

Kusmana, C., and Susanti, S. 2015. Komposisi dan Struktur Tegakan Hutan Alam di Hutan Pendidikan Gunung Walat, Sukabumi. Jurnal Silvikultur Tropika 5(3): 210-217.

Lahrita, L., Kato, E., and Kawabata, J. 2015. Uncovering Potential of Indonesian Medicinal Plants on Glucose Uptake Enhancement and Lipid Suppression in 3T3-L1 Adipocytes. Journal of Ethnopharmacology 168: 229-236. DOI: 10.1016/j.jep.2015.03.082

Low, B. S., Das, P. K., and Chan, K. L. 2013. Standardized Quassinoid-Rich Eurycoma longifolia Extract Improved Spermatogenesis and Fertility in Male Rats via the HypothalamicPituitary-Gonadal Axis. Journal of Ethnopharmacology 149: 706-714. DOI: 10.1016/j.jep.2012.11.013

Mishra, A., S. Behera, S., Singh, K., Chaudhary, L., Mishra, R., and Singh, B. 2013. Influence of Abiotic Factors on Community Structure of Understory Vegetation in Moist Deciduous Forests of North India. Forest Science and Practice 15: 261-273. DOI: 10.1007/s11632013-0415-3

Naidu, M. T., and Kumar, O. A. 2016. Tree Diversity, Stand Structure, and Community Composition of Tropical Forests in Eastern Ghats of Andhra Pradesh, India. Journal of AsiaPacific Biodiversity 9 (3): 328-334. DOI: 10.1016/j.japb.2016.03.019

Pamoengkas, P., and Exze, E. 2019. Struktur Tegakan Tanaman Meranti Tembaga (Shorea Leprosula Miq.) di Hutan Penelitian Haurbentes, Jasinga. Jurnal Pengelolaan Sumberdaya Alam dan Lingkungan 9(1): 61-67. DOI: 10.29244/jps1.9.1.61-67

Pant, S., and Samant, S. 2012. Diversity and Regeneration Status of Tree Species in Khokhan Wildlife Sanctuary, North-Western Himalaya. Tropical Ecology 53(3): 317-331.

Rawat, D. S., Dash, S. S., Sinha, B. K., Kumar, V., Banerjee, A., and Singh P. 2018. Community Structure and Regeneration Status of Tree Species in Eastern Himalaya: A Case Study From Neora Valley National Park, West Bengal, India. Taiwania 63(1): 16-24. DOI: 10.6165/tai.2018.63.16

Rosmaina, and Zulfahmi. 2013. Genetic Diversity of Eurycoma longifolia Jack based on Random Amplified Polymorphic DNA Marker. Jurnal Manajemen Hutan Tropika 19(2): 138-144. DOI: $10.7226 / \mathrm{jtfm} \cdot 19.2 .138$

Rozak, A. H., Astutik, S., Mutaqien, Z., Widyatmoko, D., Sulistyawati, E., and Widyatmoko, D. 2020. Efektivitas Penggunaan Tiga Indeks Keanekaragaman Pohon dalam Analisis Komunitas Hutan: Studi Kasus di Taman Nasional Gunung Gede Pangrango, Indonesia. Jurnal Penelitian Hutan dan Konservasi Alam 17(1): 35-47. DOI: 10.20886/jphka.2020.17.1.35-47

Sarkar, M., and Devi, A. 2014. Assessment of Diversity, Population Structure and Regeneration Status of Tree Species in Hollongapar Gibbon Wildlife Sanctuary, Assam, Northeast India. Tropical Plant Research 1(2): 26-36.

Saridan, A., and Soegiharto, S. 2010. Struktur Tegakan Tinggal pada Uji Coba Pemanenan di Hutan Penelitian Labanan, Kalimantan Timur. Jurnal Penelitian Hutan dan Konservasi Alam 9(3): 239-249. DOI: 10.20886/jphka.2012.9.3.239-249

Sihotang, V. B. L., and Rahmawati, K. 2019. Politik Usaha Pengumpulan dan Perdagangan Pasak Bumi: strategi UD Alam Lestari dan Masyarakat Pengumpul Pasak Bumi di Kecamatan Bahorok, Sumatera Utara. In Prosiding Seminar Nasional Konservasi dan Pemanfaatan 
Tumbuhan dan Satwa Liar. Riset Sebagai Fondasi Konservasi dan Pemanfaatan Tumbuhan dan Satwa Liar. (P 525). Bogor Jabar: LIPI.

Sharma, C., Mishra, A, K., Prakash, O., Dimri, S., and Baluni, P. 2014. Assessment of Forest Structure and Woody Plant Regeneration on Ridge Tops at Upper Bhagirathi Basin in Garhwal Himalaya. Tropical Plant Research 1: 62-71.

Siburian, R. H. S., Trirbo, M., and Anggrianto, R. 2020. Growing Site Characteristics of Agathis labillardieri Warb in the Natural Forests of Siwi Momiwaren, West Papua. Jurnal Sylva Lestari 8(3): 297-307. DOI: 10.23960/js138297-307

Siraj, M., and Zhang, K. 2018. Structure and Natural Regeneration of Woody Species at Central Highlands of Ethiopia. Journal of Ecology and the Natural Environment 10 (7): 147-158. DOI: $10.5897 /$ jene2018.0683

Su, D., Yu, D., Zhou, L., Xie, X., and Liu, Z. 2010. Differences in the Structure, Species Composition and Diversity of Primary and Harvested Forests on Changbai Mountain, Northeast China. Journal of Forest Science 56: 285-293. DOI: 10.17221/84/2009-jfs

Susilowati, A., Rachmat. H. H., Elfiati, D., and Hasibuan, M. H. 2019a. The Composition and Diversity of Plant Species in Pasak Bumi's (Eurycoma Longifolia) Habitat in Batang Lubu Sutam Forest, North Sumatra, Indonesia. Biodiversitas 20(2): 413-418. DOI: 10.13057/biodiv/d200215

Susilowati, A., Rachmat, H. H., Elfiati, D., Kholibrina, C. R., Kusuma, Y. S., and Siregar, H. 2019b. Population Structure of Cotylelobium melanoxylon within Vegetation Community in Bona Lumban Forest, Central Tapanuli, North Sumatra, Indonesia. Biodiversitas 20(6): 1681-1687. DOI: 10.13057/biodiv/d200625

Teketay, D., Kashe, K., Madome, J., Kabelo, M., Neelo, J., Mmusi, M., and Masamba W. 2018. Enhancement of Diversity, Stand Structure and Regeneration of Woody Species through Area Exclosure: The Case of a Mopane Woodland in Northern Botswana. Ecological Processes 7: 5. DOI: 10.1186/s13717-018-0116-X

Tran, T. V. A., Malainer, C., Schwaiger, S., Atanasov, A. G., Heiss, E. H., Dirsch, V. M., and Stuppner, H. 2014. NF- $\mathrm{BB}$ inhibitors from Eurycoma longifolia. Journal of Natural Products 77: 483-488. DOI: 10.1021/np400701k

Wahyuni, N. I., and Mokodompit, H. S. 2016. Struktur, Komposisi dan Keragaman Jenis Pohon di Hutan Produksi Inobonto Poigar I, KPHP Poigar, Sulawesi Utara. Jurnal Wasian 3(1): 45-50.

Wardani, M., and Susilo, A. 2017. Evaluasi Keberadaan Shorea platyclados Slooten ex Endert di Hutan Lindung Bukit Daun. Widyariset 3(2): 151-160. DOI: 10.14203/widyariset.3.2.2017.151-160

Yuniawati, and Tampubolon, R. M. 2021. A Decrease in Carbon Absorption Potential Due to Timber Harvesting in Natural Forest. Jurnal Sylva Lestari 9(3): 389-399. DOI: 10.23960/jsl.v9i3.516 